\author{
Lidia BUDA-OŻÓG ${ }^{1}$ \\ Izabela SKRZYPCZAK ${ }^{2}$
}

\title{
EXPERIMENTAL AND NUMERICAL ANALYSIS OF CRACKS IN THE REINFORCED CONCRETE PIPES
}

\begin{abstract}
This article presents the analysis of the cracks in the tensile strength of concrete for reinforced concrete pipe crushing. Tensile strength, in case of crushing elements of high relative curvature, is significantly different from the strength of the not curved elements. The current state of research indicates that only methods of nonlinear fracture mechanics lead to a satisfactory agreement between the results of calculations and experimental studies, and allow for compiling correctly the influence of basic parameters of stretched concrete and geometrical dimensions on the load capacity of crush pipes made of concrete. Obtaining consistent results of experimental and numerical research is still a very complicated issue. This paper presents the results of an experimental test performed on three pipes and the numerical model of the analyzed element of the pipes made in the ATENA program. In order to model the concrete we used material model "SBETA", proposed by ATENA. The numerical analyses of the cracks were compared with the results of experimental studies in this paper. The conducted experimental test indicate that the concrete tensile strength for the tested elements was higher than adopted. This resulted in a greater resistance of the cracking for the test elements.
\end{abstract}

Keywords: reinforced concrete, pipes, cracks, crushing, tensile strength

\section{Introduction}

Compliance of theories of concrete cracking with the results of experimental studies is much weaker than in the case of the theory of strength limit; the cracking issue is very complex and depends on many poorly controlled factors. One of these is the tensile strength of concrete. Tensile strength, in case of crushing elements of high relative curvature, is significantly different from the strength of the not curved elements.

\footnotetext{
${ }^{1}$ Author for correspondence: Lidia Buda-Ozog, Rzeszow University of Technology, Poznanska 2, 35-084 Rzeszow, tel.: +48 17 7432402, e-mail: lida@prz.edu.pl,

2 Izabela Skrzypczak, Rzeszow University of Technology, izas@prz.edu.pl
} 
The current state of research indicates that only methods of nonlinear fracture mechanics lead to a satisfactory agreement between the results of calculations and experimental studies, and allow for compiling correctly the influence of basic parameters of stretched concrete and geometrical dimensions on the load capacity of crush pipes made of concrete $[4,5]$.

An attempt to apply the model to describe the band microcracks of scale effect from the failure of concrete pipes presented Z. Bazant and Z. Cao [1]. However, obtaining consistent results of experimental and numerical research is still a very complicated issue. This article presents the analysis of the cracks in the tensile strength of concrete for reinforced concrete pipe crushing. The relationships between crushing load capacity of reinforced concrete pipes with concrete tensile strength and dimensions of pipes is proposed in the article.

This paper presents the results of an experimental test performed on three pipes and the numerical model of the analyzed element of the pipes made in the ATENA program. In this paper the numerical analyses of the cracks were compared with the results of experimental studies. On the basis of analyses and experimental tests, the effect of curvature of the cross-section on the tensile strength of concrete in the reinforced concrete pipes crushed was determined.

\section{Analyzed reinforced concrete pipes}

The subject of the analysis was reinforced concrete pipe with an inner diameter of $800 \mathrm{~mm}$ and wall thickness of $90 \mathrm{~mm}$. Specific dimensions of the pipes are shown in Figure 1.
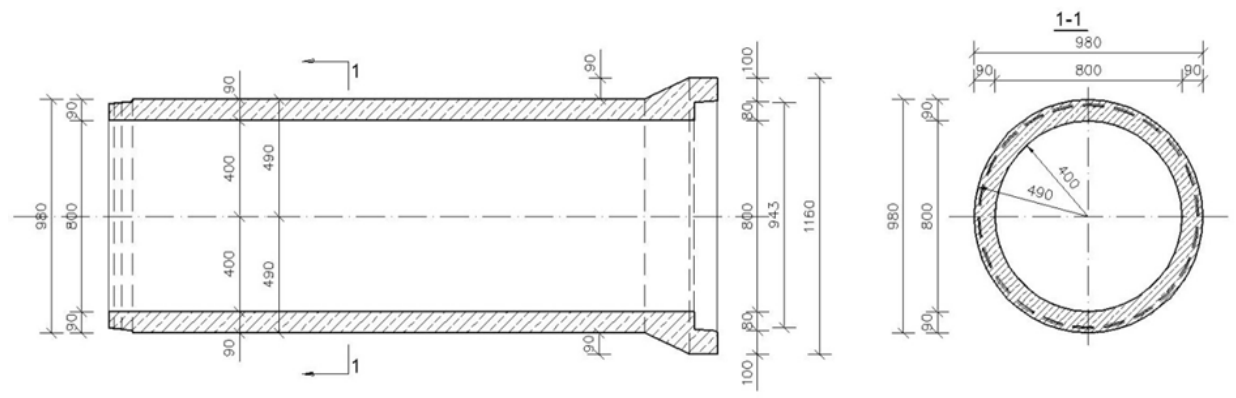

Fig. 1. Analyzed reinforced concrete pipes

Rys. 1. Rozważana rura żelbetowa

The pipes were made of concrete about mean value of compressive strength $\mathrm{f}_{\mathrm{cm}}=47.8 \mathrm{~N} / \mathrm{mm}^{2}$ and the standard deviation $\mathrm{s}=4.19 \mathrm{~N} / \mathrm{mm}^{2}$. The mean strength of the concrete was obtained by means of a compressive test performed on four $150 \mathrm{~mm}$ size cubes. 
In analysis of concrete structures the characteristic compressive strength $f_{c k}$ is calculated from the ratio [6]:

$$
\mathrm{f}_{\mathrm{ck}}=\mathrm{f}_{\mathrm{cm}}-4=47.8-4=43.8 \mathrm{~N} / \mathrm{mm}^{2}
$$

The modulus of elasticity $-\mathrm{E}_{\mathrm{c}}$ in $\left[\mathrm{N} / \mathrm{mm}^{2}\right]$ at concrete age of 28 days was obtained by means of a test for the stress-strain relation for uniaxial compression. The mean modulus of elasticity for the analyzed concrete was:

$\mathrm{E}_{\mathrm{c}}=28600 \mathrm{~N} / \mathrm{mm}^{2}$

The pipes were reinforced with bars of $\phi 10 \mathrm{~mm}$, steel RB500W of C class with reinforcement field of $872 \mathrm{~mm}^{2}$. The adopted cover of main reinforcement and the reinforcement spacing is shown in Figure 2.

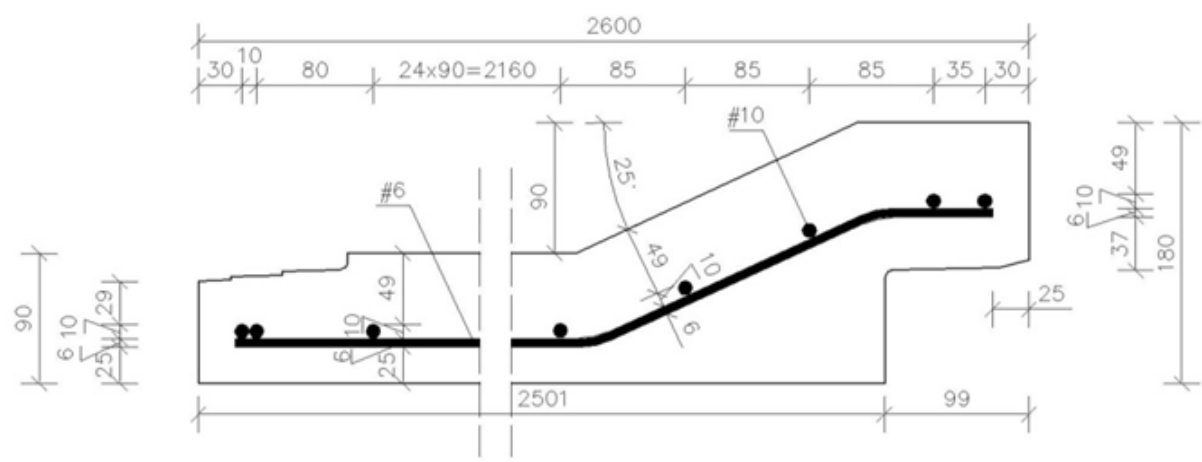

Fig. 2. The adopted cover of main reinforcement and the reinforcement spacing for analyzed the pipes Rys. 2. Przyjęta otulina zbrojenia głównego i rozstaw zbrojenia w rozpatrywanej rurze

The analysis of the crack was performed for the diagram of test load of pipes, adopted in accordance with the recommendations of EN 1916:2005/AC. The adopted load diagram is shown in Figure 3.

Calculation and analysis were applied for cracks marked in Figure 3, points $\mathrm{A}$ and $\mathrm{B}$.

In accordance with the recommendations in EN-1916:2005/AC [7] and the producer's requirements, except for condition of strength capacity, reinforced concrete pipes should meet the cracking condition. Reinforced concrete pipe shall withstand a test load due to cracking failure force $\mathrm{Fc}$ equal to 0.67 without the emergence of fixed cracks of the surface greater than $0.3 \mathrm{~mm}$ in the continuous length of $300 \mathrm{~mm}$ or more in stretched zones of concrete. 


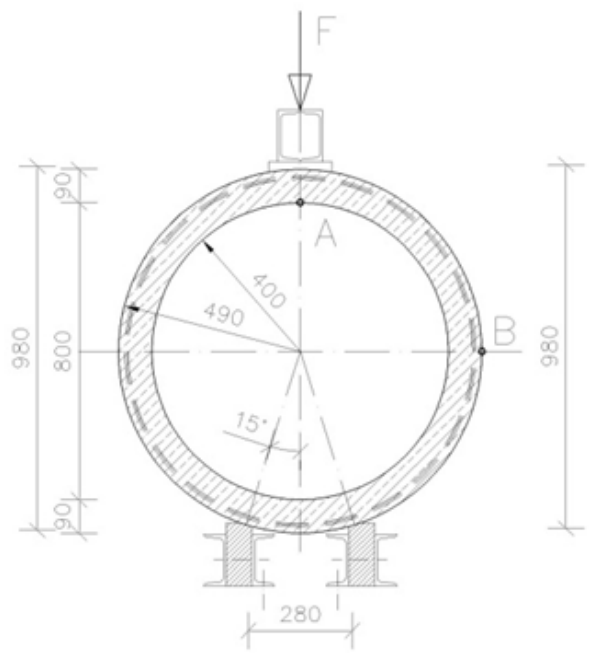

Fig. 3. Load diagram of pipes

Rys. 3. Schemat obciążenia rury

\section{Effect of curvature of the cross-section in the tensile strength of concrete}

The energy condition of unstable crack development, i.e. (that is) failure without considering the influence of curvature on the section is as follows:

$$
\frac{\partial \mathrm{U}}{\partial \mathrm{a}}=\mathrm{G}_{\mathrm{F}} * \mathrm{l}
$$

where: $U=U_{1}+U_{2}-$ potential energy release rate of deformation in the volume of the zone of destruction $\mathrm{U}_{1}$ and the adjacent concrete $\mathrm{U}_{2}$, $\mathrm{G}_{\mathrm{F}}$ - cracking energy, 1- element length.

According to what is indicated in Figure 4, it can be assumed that:

$$
\frac{\partial \mathrm{U}}{\partial \mathrm{a}}=\mathrm{l} * \frac{\sigma}{2 * \mathrm{E}_{\mathrm{ct}}}\left(2 \mathrm{a}+\mathrm{w}_{\mathrm{c}}\right)
$$

where: $\sigma$-mean normal stress, Ec- modulus of elasticity of concrete. 


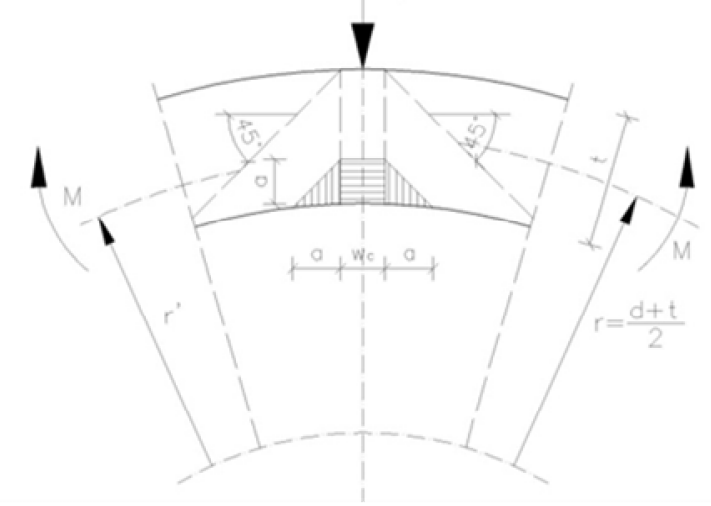

Fig. 4. Diagram of micro crack propagation on the thickness of the pipe wall Rys. 4. Wykres propagacji mikrorys na grubości ścianki rury

Ratio of the maximum stress calculated having taken into account the curvature of the axis $\sigma^{*}$ to the stresses set for the element with straight axis $\sigma$, is:

$$
\frac{\sigma^{*}}{\sigma}=\frac{\mathrm{t}}{6 * \mathrm{r}^{\prime}}+\frac{2 * \mathrm{r}^{\prime} * \mathrm{z}}{\mathrm{t} *\left(\mathrm{r}^{\prime}-\mathrm{z}\right)} * \frac{\mathrm{J}}{\mathrm{J}^{*}}=\beta\left(\frac{\mathrm{t}}{\mathrm{r}}\right)
$$

where $: z=r^{\prime}-d / 2, d$ - inner diameter of the pipe,

$\mathrm{J}$ - moment of inertia of the element with straight axis,

$\mathrm{J}^{*}$ - moment of inertia of the element with flexural curved expressed by the formula:

$$
\mathrm{J}^{*}=\int_{\mathrm{A}} \frac{\mathrm{r}}{\mathrm{r}+\mathrm{z}} * \mathrm{z}^{2} \mathrm{dA}
$$

Tensile strength of concrete by crushing, taking into account the impact of the relative curvature of the pipe cross-section, can be represented as follows:

$$
\mathrm{f}_{\mathrm{ctm}}^{*}=\mathrm{f}_{\mathrm{ctm}} * \sqrt{\frac{2}{\beta}} *\left(\frac{\mathrm{l}_{\mathrm{ch}}}{2 * \mathrm{t}+\mathrm{w}_{\mathrm{c}}}\right)^{\frac{1}{2}}
$$

$1_{\mathrm{ch}}$ - characteristic length of concrete: $\quad \mathrm{l}_{\mathrm{ch}}=\frac{\mathrm{G}_{\mathrm{F}} * \mathrm{E}_{\mathrm{c}}}{\mathrm{f}_{\mathrm{ct}}^{2}}$, $\mathrm{f}_{\mathrm{ct}}$ - tensile strength of concrete,

$$
\mathrm{f}_{\mathrm{ct}}=0.3 *\left(\mathrm{f}_{\mathrm{ck}}\right)^{\frac{2}{3}}=0.3 *(43.8)^{\frac{2}{3}}=3.73 \mathrm{~N} / \mathrm{mm}^{2}
$$


In the absence of experimental value of the fracture energy $-\mathrm{G}_{\mathrm{F}}$, it can be determined in accordance with the Model Code 2010 [8] by dependencies:

$$
\begin{aligned}
& \mathrm{G}_{\mathrm{F}}=73 *\left(\mathrm{f}_{\mathrm{cm}}\right)^{0,18} \\
& \mathrm{G}_{\mathrm{F}}=73 *(47.8)^{0,18}=146.43 \mathrm{~N} / \mathrm{m} \\
& \mathrm{l}_{\mathrm{ch}}=\frac{146.43 * 28.6}{3.73^{2}}=301 \mathrm{~mm}
\end{aligned}
$$

Moment of inertia of the element with curved axis, for $r \approx 5 * t$, amounts to:

$$
\mathrm{J}^{*}=1.009 * \frac{1 * \mathrm{t}^{3}}{12}=61.3 * 10^{6} \mathrm{~mm}^{4}
$$

Substituting into the formula (3), we received $\beta=1.27$.

For a pipe with an internal diameter $\mathrm{d}=800 \mathrm{~mm}$ and a wall thickness $\mathrm{t}=90 \mathrm{~mm}$, made of concrete $\mathrm{C} 35 / 45$, the bandwidth of micro cracks $\mathrm{w}_{\mathrm{c}}=26 \mathrm{~mm}$, we obtain the tensile strength of concrete by crushing, taking into account the impact of the relative curvature of the cross section:

$$
\mathrm{f}_{\mathrm{ctm}}^{*}=3.73 * \sqrt{\frac{2}{1.27}} *\left(\frac{301}{2 * 90+26}\right)^{\frac{1}{2}}=5.66 \mathrm{~N} / \mathrm{mm}^{2}
$$

\section{Experimental Test}

The test was carried out on three pipes made of a single batch of concrete and reinforced in the same way. The test was made at Civil Engineering, Environmental Engineering and Architecture Lab, Rzeszow University of Technology. A series of step loaded static tests were aimed at producing successive damage to the pipes. The development of cracks under different loading conditions was analyzed during the test. The setup of static testing is shown in Figure 5.

Fig.5. The setup of testing

Rys. 5. Układ badawczy

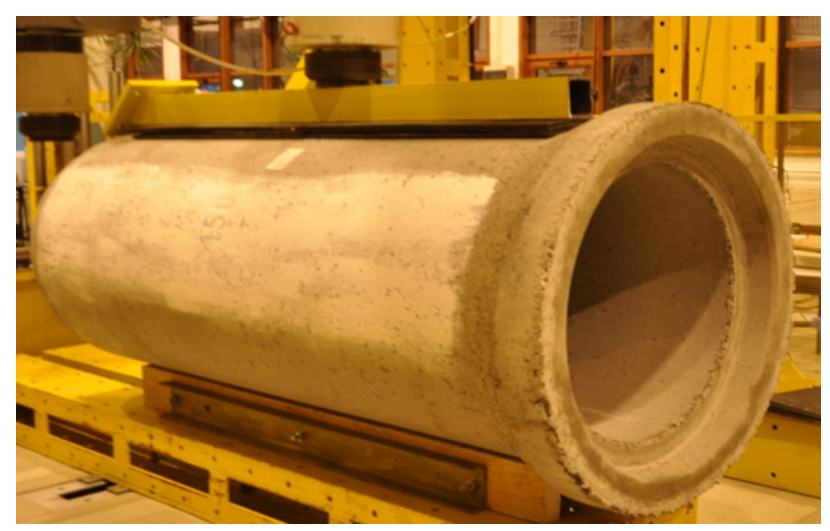


Test results of experimental for three tested pipes are summarized in Tables 1 . The point $B$ in the table shows the values of strength at which the first scratch and crack of width $0.3 \mathrm{~mm}$ over a length greater than $300 \mathrm{~mm}$ were observed.

Table 1. Results of experimental test for three tested pipes

Tabela 1. Wyniki badań doświadczalnych trzech badanych rur

\begin{tabular}{|l|c|c|c|}
\hline Element & $\begin{array}{c}\text { Crack loading at } \\
\text { point B } \\
{[\mathrm{kN} / \mathrm{m}]}\end{array}$ & $\begin{array}{c}\text { Loading for crack 0,3 } \\
\mathrm{mm} \\
{[\mathrm{kN} / \mathrm{m}]}\end{array}$ & $\begin{array}{c}\text { Failure loading } \\
{[\mathrm{kN} / \mathrm{m}]}\end{array}$ \\
\hline P 1 & 63.6 & 76.0 & 148.8 \\
\hline P 2 & 60.0 & 71.6 & 132.0 \\
\hline P 3 & 62.8 & 74.8 & 129.6 \\
\hline mean & 62.1 & 74.1 & 136.8 \\
\hline
\end{tabular}

The failure was caused by the rapid rise of cracks at the point B and compression failure at the point A. The Figure 6 presents the crack width of $0.1 \mathrm{~mm}$ at the point $\mathrm{B}$ and failure for tested pipes.

a)

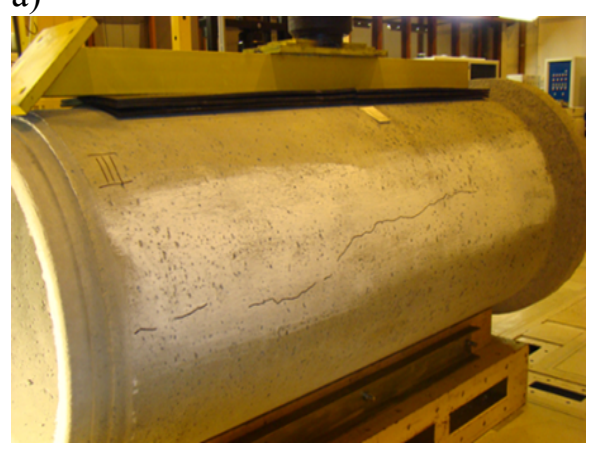

b)

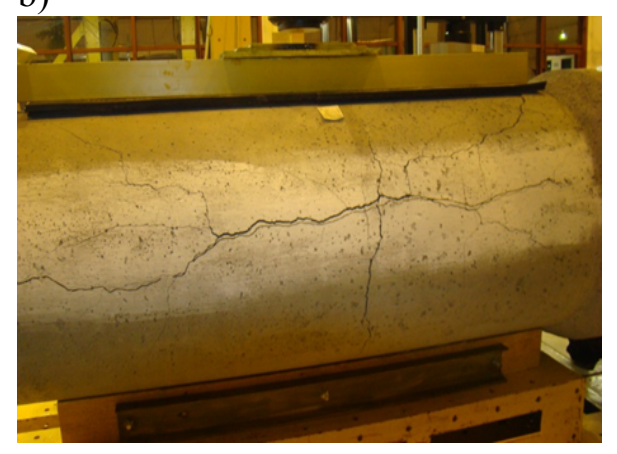

Fig.6. Pipe during the experimental test, a) the crack width of $0.1 \mathrm{~mm}$ at the point $\mathrm{B}, \mathrm{b}$ ) failure Rys. 6. Rura podczas badań, a) rysy szerokości $0,1 \mathrm{~mm}$ w punkcie B. b) zniszczenie rury

\section{Numerical model of the analyzed pipe}

Finite element method was applied for the construction of the numerical model of the analyzed pipes. MES programming of ATENA was used.

Numerical model was considered in three-dimensional stress state. In order to solve the static issues of reinforced concrete pipes, calculation procedure based on Newton- Raphson iterative method was used [2]. Newton-Raphson method keeps the load increment unchanged and iterates displacements until equilibrium is satisfied within the given tolerance. 
In order to model the concrete we used material model "SBETA", proposed by ATENA. The material model SBETA includes the following effects of concrete behavior:

-non-linear behavior in compression including hardening and softening,

- fracture of concrete in tension based on the nonlinear fracture mechanics,

- biaxial strength failure criterion,

- reduction of compressive strength after cracking,

- tension stiffening effect,

- reduction of the shear stiffness after cracking,

- two crack models: fixed crack direction and rotated crack direction.

Perfect bond between concrete and reinforcement is assumed within the smeared concept.

However, on a macro-level a relative slip displacement of reinforcement with respect to concrete over a certain distance can arise, if concrete is cracked or crushed. This corresponds to a real mechanism of bond failure in case of the bars with ribs.

The reinforcement in both forms, smeared and discrete, is in the uniaxial stress state and its constitutive law is a multi-linear stress-strain diagram [3].

The model of material was adopted on the basis of constitutive characteristics obtained from experimental tests. The basic constitutive characteristics of the concrete are shown in a Table 2.

Table 2. The basic material characteristics of material model "SBETA"

Tabela 2. Podstawowe charakterystyki materiałowe model "SBETA”

\begin{tabular}{|l|c|}
\hline Tangent Modulus [N/mm $\left.{ }^{2}\right]$ & 28600 \\
\hline Uniaxial Cut-Off Tensile Stress [N/mm $\left.{ }^{2}\right]$ & 5.66 \\
\hline Fracture energy [N/m] & 146.43 \\
\hline Uniaxial Maximum Compressive Stress [N/mm $\left.{ }^{2}\right]$ & 47.8 \\
\hline Uniaxial Maximum Compressive Strain at Above Stress & 0.002 \\
\hline Uniaxial Ultimate Compressive Stress [N/mm $\left.{ }^{2}\right]$ & 29.8 \\
\hline Uniaxial Ultimate Compressive Strain & 0.0035 \\
\hline Poisson Ratio & 0.167 \\
\hline
\end{tabular}

In order to model the main reinforcement we used material model "reinforcement", proposed by ATENA. The model of elastic-plastic material, with characteristics corresponding to steel RB500W was used. The characteristics of steel reinforcement are summarized in Table 3.

The analyzed pipes were loaded by forces of values corresponding to the experimental tests. Numerical model of the analyzed pipe is shown in Figure 7. The numerical model was built for a repeatable fragment of the pipe. 
Table 3. The basic material characteristics of material model "reinforcement"

Tabela 3. Podstawowe charakterystyki materiałowe model ,reinforcement"

\begin{tabular}{|l|l|}
\hline Young's Modulus [N/mm $\left.{ }^{2}\right]$ & 200000 \\
\hline Initial Yield Stress [N/mm $\left.{ }^{2}\right]$ & 500 \\
\hline Strain Hardeninig Modulus [N/mm $\left.{ }^{2}\right]$ & 2000 \\
\hline Poisson Ratio & 0.3 \\
\hline
\end{tabular}

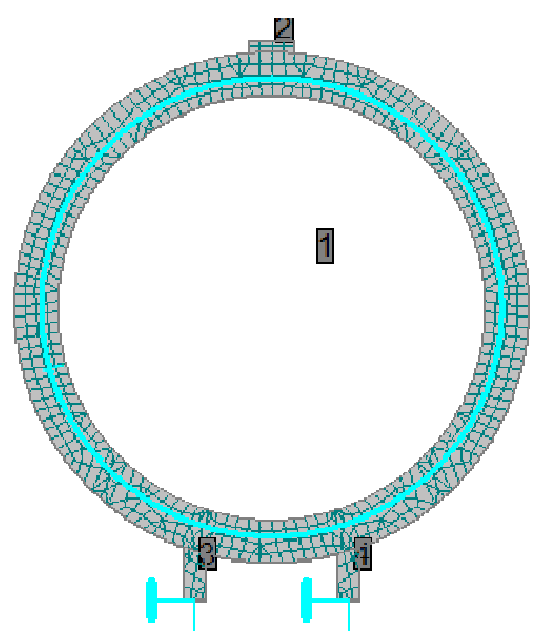

Fig. 7. Numerical model of the analyzed fragment of the pipe Rys. 7. Numeryczny model analizowanego fragmentu rury

Development of scratches depending on the applied load are shown in the Figure 8.

\section{Analyzes the Results and Conclusions}

The applied load depending on the cracks observed at point B for experimental and numerical test are summarized in Table 4.

In all analyzed cases, the crack loading from experimental studies were greater about $9 \%$ in comparison with the crack loading obtained from the numerical model.

Table 4. The applied load depending on the cracks at point B

Tabela 4. Przyłożone obciążenie zależne od zarysowania w punkcie B

\begin{tabular}{|l|l|l|}
\hline \multirow{2}{*}{ Cracks at point B } & \multicolumn{2}{|c|}{ Applied load [kN/m] } \\
\cline { 2 - 3 } & Experimental test & Numerical model \\
\hline First crack at point B & 62.1 & 56.3 \\
\hline Crack width of $0.3 \mathrm{~mm}$ & 74.1 & 68.7 \\
\hline Failure & 136.8 & 132.0 \\
\hline
\end{tabular}


a) step 62, cracks width to $0.001 \mathrm{~mm}$

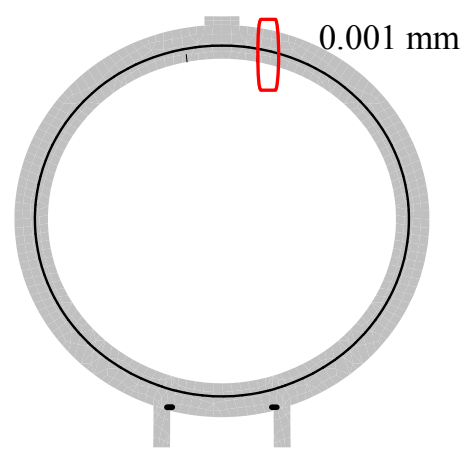

c) step 78 , cracks width to $0.3 \mathrm{~mm}$

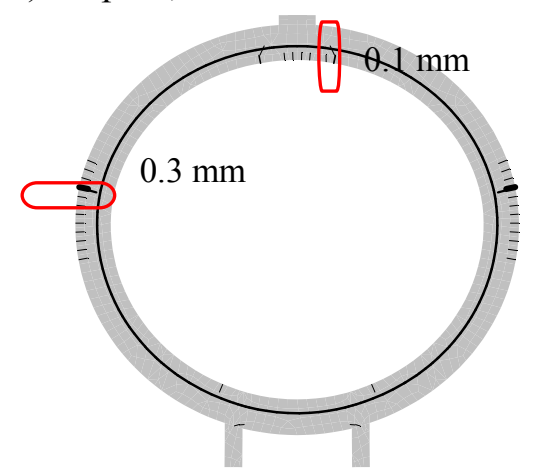

b) step 65 , cracks width to $0.014 \mathrm{~mm}$

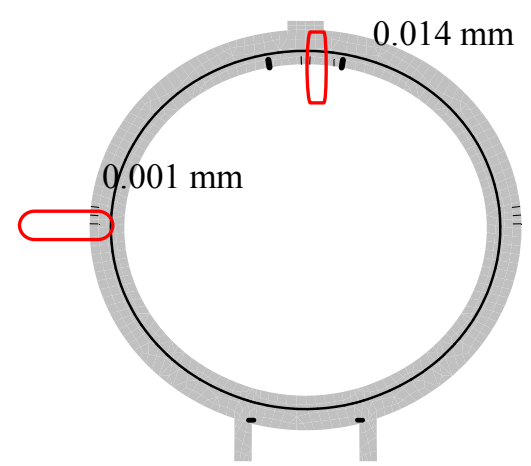

d) step 170, cracks width to $1.08 \mathrm{~mm}$

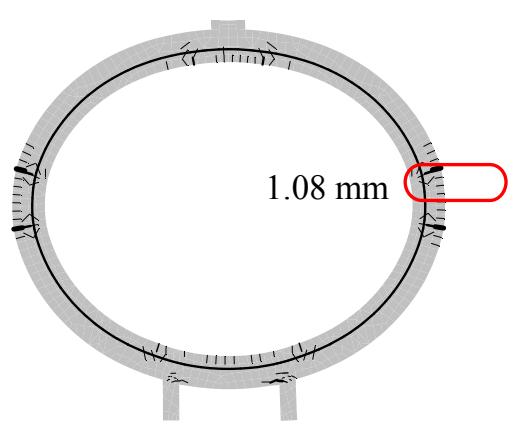

Fig. 8. Development of scratches and deformation depending on the applied load, a) the first cracks at the point $\mathrm{A}$, force $\mathrm{F}=53.55 \mathrm{kN} / \mathrm{m}, \mathrm{b}$ ) the first cracks at the point $\mathrm{B}$, force $\mathrm{F}=56.5 \mathrm{kN} / \mathrm{m}, \mathrm{c}$ ) the crack width of $0.3 \mathrm{~mm}$ at the point $\mathrm{B}$, force $\mathrm{F}=68.7 \mathrm{kN} / \mathrm{m}$, d) failure, the crack width above $1 \mathrm{~mm}$, force $\mathrm{F}=132 \mathrm{kN} / \mathrm{m}$

Rys. 8. Rozwój zarysowań i odkształceń zależnie od przyłożonego obciążenia, a) pierwsze pęknięcia w punkcie $A$, siła $F=53.55 \mathrm{kN} / \mathrm{m}, \mathrm{b}$ ) pierwsze pęknięcia $\mathrm{w}$ punkcie $\mathrm{B}$, siła $\mathrm{F}=56.5 \mathrm{kN} / \mathrm{m}$, c) rysa szerokości $0.3 \mathrm{~mm}$ w punkcie $\mathrm{B}$, siła $\mathrm{F}=68.7 \mathrm{kN} / \mathrm{m}$, d) zniszczenie, rysy szerokości większej niż $1 \mathrm{~mm}$, siła $\mathrm{F}=132 \mathrm{kN} / \mathrm{m}$

The development of scratches obtained through the experimental test is analogous to that obtained using the numerical model. The load mean for cracks of the width of $0.3 \mathrm{~mm}$ obtained from the experimental test are larger about $8 \%$ in comparison with the numerical analysis.

Summing up the performed numerical analysis and experimental test results, the relationship between the geometric dimensions of the pipes and their load capacity can be noticed. 
Analytically determined tensile strength of concrete taking into account the impact of the relative curvature of the pipe cross-section is almost $65 \%$ large as proposed in EN-1992-1-1 and Model Code 2010

The conducted experimental test indicate that the concrete tensile strength for the tested elements was higher than adopted. This resulted in a greater resistance of the cracking for the test elements.

As demonstrated by the analysis, the correct specification of the concrete tensile strength in crushing, taking into account the effect of curvature of the cross-section is important for the optimal design of pipe elements.

\section{Bibliography}

[1] Bazant Z. P, Cao Z., "Size effect in brittle failure of unreinforced pipes". Report 852/679s. Center for Concrete and Geometrials, Northwestern Unive., Evanstone, Illinois 1985 .

[2] Crisfield M.A, Non-linear Finite Element Analysis of Solid and Structures, John Wile\& Soons,INC, England, 1997.

[3] Červenka V., Jendele L., Červenka J., “ATENA Program Documentation- Theory”, Prague, September 19, 2014.

[4] Wallbrink C.D, Peng D., Jones R., "Assessment of partly circumferential cracks in pipe", International Journal of Fracture, May 2005, Volume 133, Issue 2,

[5] Woliński Sz., "Tensile Behaviour of Concrete and Their Applications in Nonlinear Fracture Mechanics of Concrete" Zeszyty Naukowe PRz, Rzeszów 1991(in polish).

[6] EN- 206:2013 Concrete. Specification, performance, production and conformity,

[7] EN-1916:2005/AC Concrete pipes and fittings unreinforced, steel fibre and reinforced

[8] CEB-FIP Model Code 2010, Bulletin d'Information

\section{ANALIZA DOŚWIADCZALNA I NUMERYCZNA PĘKNIĘĆ W RURACH ŻELBETOWYCH}

\section{Streszczenie}

Artykuł przedstawia analizę pęknięć w strefie rozciąganej betonu w żelbetowych rurach poddanych zgniataniu. Wytrzymałość na rozciąganie, w przypadku zgniatania elementów o dużej krzywiźnie względnej, różni się znacznie w stosunku do wytrzymałości elementów niezakrzywionych. Bieżący stan badań wskazuje, że jedyne metoda nieliniowej mechaniki pękania daje zadawalającą zbieżność między wynikami obliczeń a badaniami doświadczalnymi i pozwala na poprawne zestawienie wpływu podstawowych parametrów spękanego betonu i wymiarów geometrycznych na nośność zgniatanej rury betonowej. Otrzymanie zgodności wyników badań doświadczalnych i analiz liczbowych jest wciąż bardzo skomplikowaną kwestią. Artykuł prezentuje wyniki badań doświadczalnych przeprowadzonych na trzech rurach żelbetowych i model numeryczny badanych elementów rurowych wykonany w programie ATENA. Jako materiałowy model betonu wykorzystano, proponowany przez program ATENA, model materiałowy "SBETA". Numeryczne analizy pęknięć zostały porównane z wynikami badań doświadczalnych. Obserwacje prowadzone podczas badań doświadczalnych wskazują, 
że wytrzymałość betonu na rozciąganie w analizowanych elementach była wyższa niż przyjęta w modelu numerycznym. Skutkowało to zwiększoną wytrzymałością ze względu na zarysowanie badanych elementów.

Słowa kluczowe: żelbet, rury, pękanie, zgniatanie, wytrzymałość na rozciąganie

Przestano do redakcji:8.06.2015

Przyjęto do druku:1.12.2015

DOI: $10.7862 / \mathrm{rb} .2015 .140$ 